\title{
MINERAL RESOURCE POTENTIAL OF THE DIRTY DEVIL, FRENCH SPRING-HAPPY CANYON, AND HORSESHOE CANYON WILDERNESS STUDY AREAS, WAYNE AND GARFIELD COUNTIES, UTAH
}

\author{
By
}

\author{
R. F. Dubiel, M. J. Larson, Fred Peterson, and W. R. Willson, \\ U.S. Gealogical Survey \\ and \\ R. A. Schreiner, U.S. Bureau of Mines
}

STUDIES RELATED TO WILDERNESS

Bureau of Land Management Wilderness Study Areas

The Federal Land Policy and Management Act (Public Law 94-579, October 21, 1976) requires the U.S. Geological Survey and the U.S. Bureau of Mines to conduct mineral surveys on certain areas to determine the mineral values, if any, that may be present. Results must be made available to the public and be submit ted to the President and the Congress. This report presents the results of a mineral survey of the Dirty Devil (UT-050236A), French Spring-Happy Canyon (UT-050-236B), and Horseshoe Canyon (UT-050-237) Wilderness Study Areas, Wayne and Garfield Counties, Utah.

\section{MINERAL RESOURCE POTENTIAL SUMMARY STATEMENT}

Field and laboratory studies of the Dirty Devil, French Spring-Happy Canyon, and Horseshoe Canyon Wilderness Study Areas in Wayne and Garfield Counties, Utah (fig. 1), were conducted to determine the resource potential of these lands. The studies indicate a moderate potential for uranium resources in the Dirty Devil Wilderness Study Area and in the extreme southwestern part of the French Spring-Happy Canyon Wilderness Study Area and a low potential for uranium resources in the northeastern part of the French Spring-Happy Canyon Wilderness Study Area and in the Horseshoe Canyon Wilderness Study Area. All three wilderness study areas have a moderate potential for petroleum resources. The French Spring-Happy Canyon Wilderness Study Area has a high potential for tar sand resources. The potential for tar sand resources in the Dirty Devil and Horseshoe Canyon Wilderness Study Areas is unknown. The studies indicate a low potential for other metallic and nonmetallic resources in the study areas.

\section{INTRODUCTION}

From 1981 to 1983, geoscientists of the U.S. Geological Survey and the U.S. Bureau of Mines conducted a field and laboratory study to evaluate the mineral resource potential of the Dirty Devil, French Spring-Happy Canyon, and Horseshoe Canyon Wilderness Study Areas (hereafter called "the study areas") in Wayne and Garfield Counties, Utah (fig. 1). The study consisted of geologic mapping (Dubiel and others, 1985), sedimentologic studies. (Peterson, 1980; Dubiel, 1983), geochemical sampling, and a study of prospects and mineralized areas. The U.S. Bureau of Mines researched the mines and prospects and investigated the exploration activity (Schreiner, 1984).

The study areas, 6-30 mi east of Hanksville, Utah, together cover about 124,800 acres (Dirty Devil, 61,000 acres; French Spring-Happy Canyon, 25,000 acres; Horseshoe Canyon, 38,800 acres) in southeastern Utah. Access to the study areas is limited to unpaved roads originating at Utah State Highway 24 about 20 mi north of Hanksville, Utah, and to unpaved roads from Green River, Utah.

\section{ACKNOWLEDGMENTS}

The development of a mineral resource potential summary of a study area is dependent upon the expertise and contributions of many people in addition to the authors. We acknowledge the assistance of our helicopter pilots, Leonard Smith, and the late Jaxon Ruby, whose skill as pilots made many of the field tasks in remote areas considerably easier. We would also like to thank the people who assisted in the field on all aspects of this interdisciplinary study: Brad Esslinger, Joseph Fontaine, Darlene Francis, David Hammond, Carl Harris, Denise Mruk, Richard Reeves, Mike Rendina, William Thoen, Ann Tirrell, Bruce van Brundt, Shawn Yasataki, and Christine Yee.

\section{GEOLOGY}

The study areas are located on the gently dipping northwest flank of the Monument upwarp and are bordered on the northwest by the steeply dipping east flank of the Sen Rafael swell; both are north-trending monoclines. Numerous joints and normal faults having 


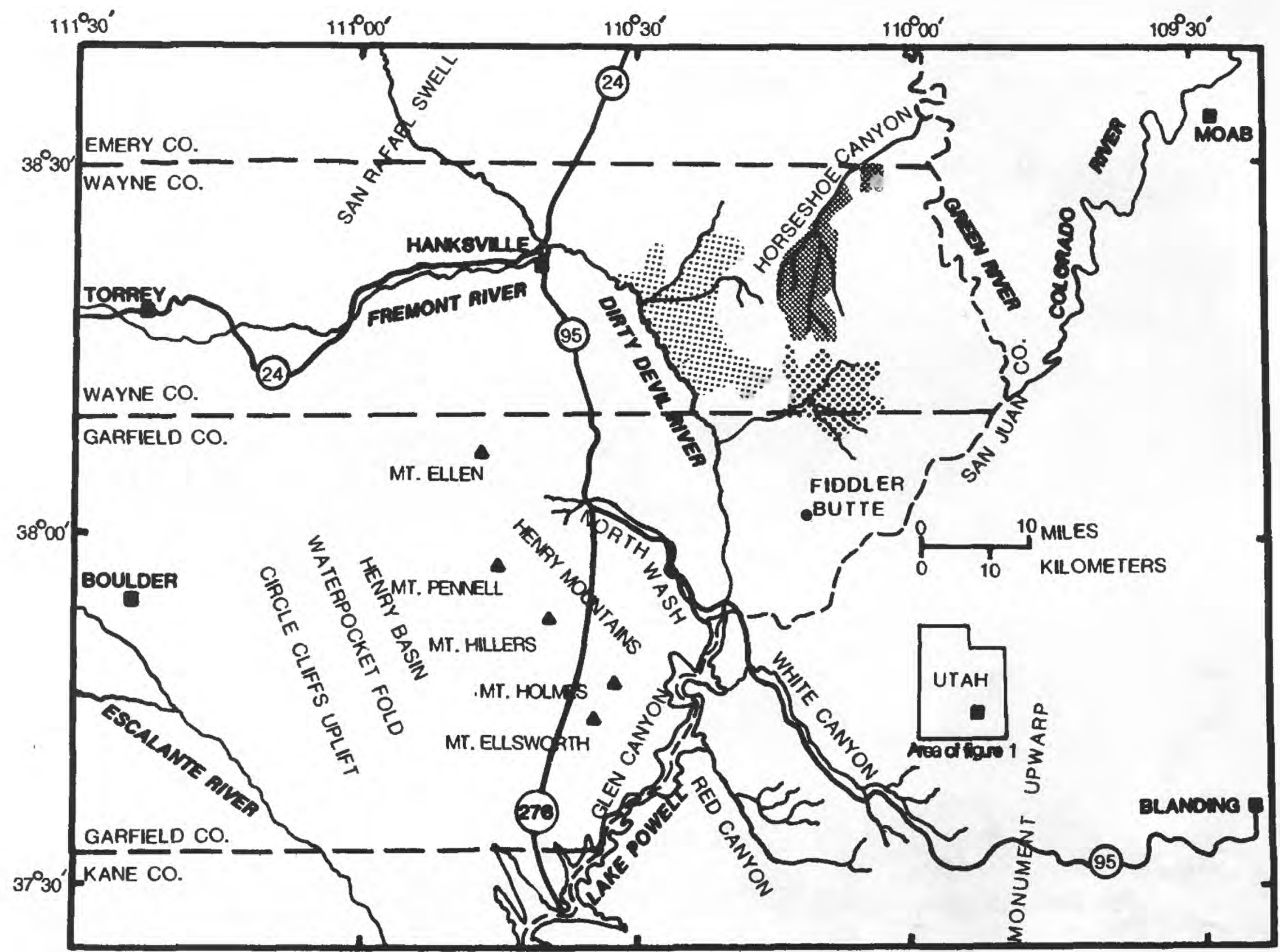

DIRTY DEVIL WILDERNESS STUDY AREA

FRENCH SPRING-HAPPY CANYON WILDERNESS STUDY AREA

HORSESHOE CANYON WILDERNESS STUDY AREA

Figure 1.--Map showing location of the Dirty Devil, French Spring-Happy Canyon, and Horseshoe Canyon Wilderness Study Areas, Wayne and Garfield Counties, Utah. 
minor displacement trend northwesterly across the region.

Rocks exposed in and near the study areas are sedimentary and range in age from Early Permian to Middle Jurassic (fig. 2). The strata have a combined total thickness of $2,600 \mathrm{ft}$ and represent deposition in marine and continental environments. The White Rim Sandstone Member of the Cutler Formation was deposited during a marine transgression in Early Permian time and represents the oldest exposed strata in the study area. Regionally, the White Rim thins to the east of the study area onto the crest of the Monument upwarp; the thinning indicates growth of this structure during the Early Permian (Baars, 1979). The Lower and Middle(?) Triassic Moenkopi Formation overlies the Cutler Formation throughout the study area and is overlain by the Upper Triassic Chinle Formation. The Glen Canyon Group overlies the Chinle Formation and consists of the following formations, in ascending order: the Wingate Sandstone (Upper Triassic), the Kayenta Formation (Upper Triassic?), and the Navajo Sandstone (Triassic? and Jurassic). Middle Jurassic formations that lie above the Navajo Sandstone include, from oldest to youngest, the Page Sandstone, the Carmel Formation, and the Entrada Sandstone of the San Rafael Group. The Quaternary terrace deposits in the Iower parts of most stream valleys comprise unconsolidated fluvial sands and gravels. Windblown sand covers much of the topographically high, but flat, areas between the major stream courses.

\section{GEOCHEMISTRY}

A reconnaissance geochemical survey of the Dirty Devil, French Spring-Happy Canyon, and Horseshoe Canyon Wilderness Study Areas was conducted during the summers of 1982 and 1983. Sample types included stream-sediment samples, heavy-mineral concentrates panned from stream sediments, and rock samples. A total of 180 streamsediment samples, 172 panned-concentrate samples, and 7 rock samples were analysed using semiquantitative emission spectrography (Grimes and Marranzino, 1968). Minerals in the heavy-mineral concentrates were also identified. A sample-locality map and a list of the data are given in Detra and others (1984).

A few stream-sediment samples have anomalous values of silver or molybdenum (HM 237, HM 287, HM 288, HM 576), and several of the heavy-mineral concentrates have anomalous values of silver, gold, or lead (HM 576, HM 307, HM 295, HM 602, HM 359). These anomalous samples are from widely scattered localities in the study areas and appear to represent small, localized mineral occurrences rather than an area of mineral resource potential. Therefore, the geochemical sampling suggests that the study areas all have low potential for metallic and nonmetallic resources.

\section{MINING DISTRICTS AND MINERALIZED AREAS}

Six prospects and three adits within and along the southern boundary of the Dirty Devil and French Spring-Happy Canyon Study Areas indicate uranium mining and associated energy-related exploration. Information from 65 drill holes in the Bull Pasture area and around the Gibex Point area in the Dirty Devil Wilderness Study Area revealed an estimated 39,000 tons of low-grade uranium ore (Schreiner, 1984).

Seventeen samples were collected from mines and prospects in and along the southern boundary of the Dirty Devil and French Spring-Happy Canyon Wilderness Study Areas. The 17 samples contained as much as 0.6 ounces silver per ton, 870 parts per million ( 0.087 percent) uranium, 25,000 parts per million (2.5 percent) copper, and 1,100 parts per million ( 0.11 percent) vanadium (Schreiner, 1984). No recorded production has come from these prospects, and because of the limited size of the occurrences no resources have been identified.

\section{ASSESSMENT OF MINERAL RESOURCE POTENTIAL}

Evaluation of the mineral resource potential of the Dirty Devil, French Spring-Happy Canyon and Horseshoe Canyon Wilderness Study Areas is based on (1) investigations of mines and prospects; (2) geochemical investigations; and (3) geologic investigations. Four levels of potential for the occurrence of mineral resources (high, moderate, low, and unknown) were defined on the basis of the following criteria.

High mineral resource potential is assigned to areas where geologic and geochemical characteristics indicate a geologic environment favorable for resource occurrence, where interpretations of data indicate a high degree of likelihood for resource accumulation, where data support mineral deposit models indicating presence of resources, and where evidence indicates that mineral concentration has taken place.

Moderate mineral resource potential is assigned to areas where geologic and geochemical characteristics indicate a geologic environment favorable for resource occurrence, where interpretations of data indicate a reasonable chance for resource accumulation, or where an application of mineral deposit models indicates favorable ground.

Low mineral resource potential is assigned to areas where geologic and geochemical characteristics define a geologic environment in which the existence of resources is unlikely.

Unknown mineral resource potential is assigned to areas where the level of knowledge is inadequate to classify an area into high, moderate, or low potential categories.

The Dirty Devil Wilderness Study Area and the extreme southwestern part of the French Spring-Happy Canyon Wilderness Study Area have a moderate potential for uranium (fig. 3). The uranium resource potential of the northeastern part of the French Spring-Happy Canyon Wilderness Study Area and all of the Horseshoe Canyon Wilderness Study Area is unknown. Uranium deposits showing minor copper and vanadium mineralization are in Triassic rocks exposed in a small area just south of the southern boundary of the Dirty Devil Wilderness Study Area and just west of the western boundary of the French Spring-Happy Canyon Wilderness Study Area (Schreiner, 1984). These deposits are small and irregularly distributed. There are no other known metallic mineral deposits in the Dirty Devil and French Spring-Happy Canyon Wilderness Study Areas. In 1981 and 1982 all uranium mines and prospects in the area were inactive. 


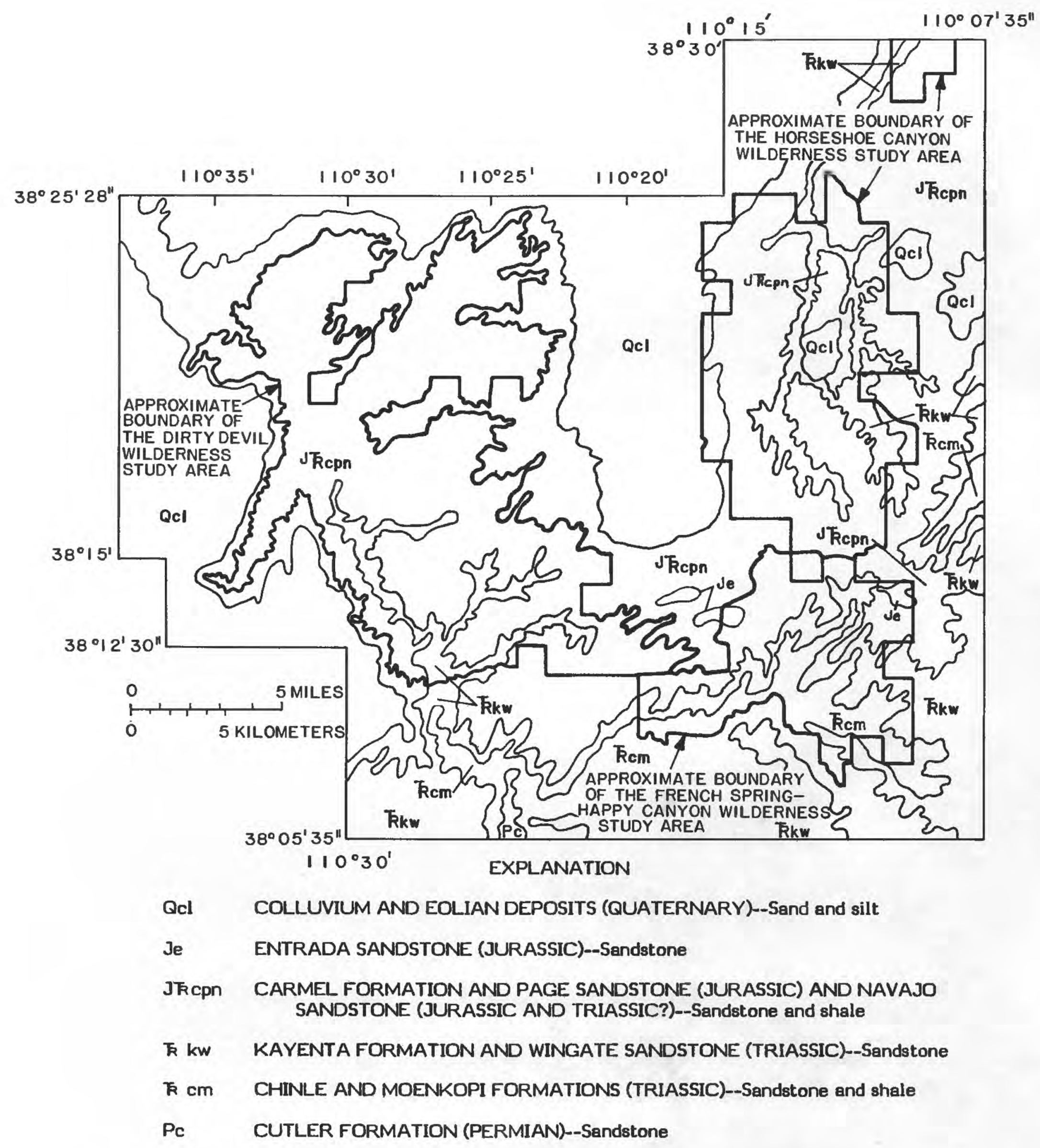

Figure 2.--Map showing generalized geologic units in the Dirty Devil, French SpringHappy Canyon, and Horseshoe Canyon Wilderness Study Areas and vicinity, Wayne and Garfield Counties, Utah. 


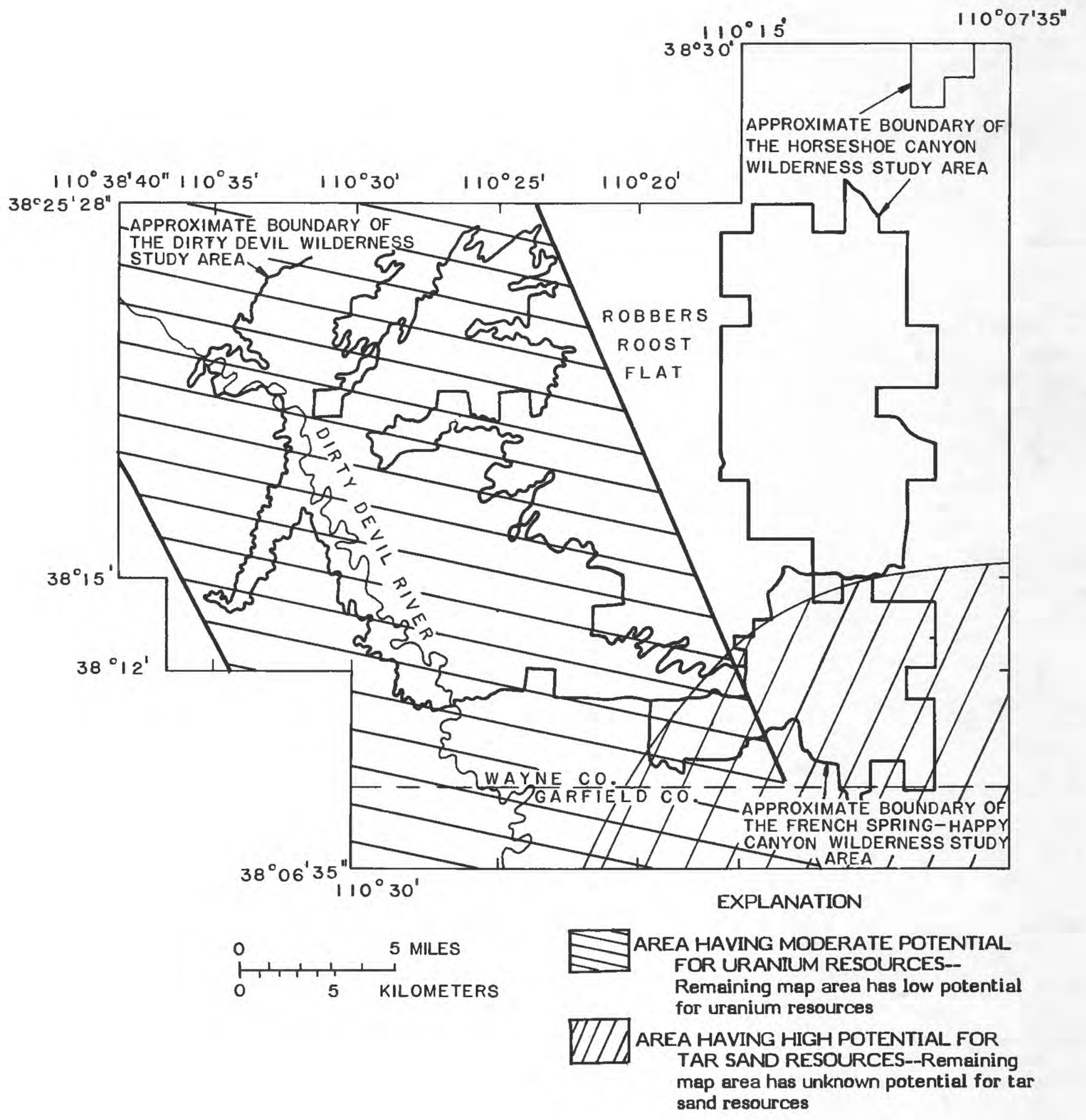

Figure 3.--Map showing mineral resource potential of the Dirty Devil, French SpringHappy Canyon, and Horseshoe Canyon Wilderness Study Areas and vicinity, Wayne and Garfield Counties, Utah. Entire map area has moderate potential for petroleum resources and low potential for both metallic and nonmetallic resources. 
The known uranium deposits in the region are restricted to fluvial sandstone beds of the Shinarump and Monitor Butte Members of the Chinle Formation. Sedimentologic analysis of the fluvial depositional systems (fig. 4) indicates that they trend north to northwest. (Dubiel, 1983) in the subsurface of the Dirty Devil Wilderness Study Area and the southwestern part of the French Spring-Happy Canyon Wilderness Study Area.

Detailed mineralogic and geochemical studies of uranium ore deposits in Jurassic rocks of the Henry basin about $20 \mathrm{mi}$ southwest of the study areas (Northrop, 1982) suggest that authigenic dolomite occurs in fluvial sandstone beds containing uranium ore deposits, either in the mineralized area or within about 1-2 mi of the mineralized areas. Rock samples from the lower part of the Chinle Formation, including the Shinarump and Monitor Butte Members, were collected for dolomite analysis where the Chinle crops out in adjoining areas just east and south of the study areas. The mineralogical analyses (done by $X$-ray diffraction) indicate that the areas of greatest concentration of dolomite coincide with the areas of the fluvial systems (fig. 4); this coincidence supports the concept that the fluvial systems may have some potential for uranium.

Detailed sedimentological studies of Jurassic rocks of the Henry basin about $15-30 \mathrm{mi}$ southwest of the study areas (Peterson, 1980) show that uranium mineralization in fluvial sandstone beds occurs where the sandstone beds are overlain or underlain by carbonaceous mudstone strata. Sedimentological studies in the Chinle (Dubiel, 1983) in areas adjacent to the study areas show concentrations of carbonaceous mudstone in the lower part of the Chinle in the same areas where the fluvial systems and the dolomite are concentrated (fig. 4). Although these criteria are suggestive of some uranium mineralization, the lack of any known significant deposits in these areas, which have been heavily prospected, suggests that large deposits do not occur there. Thus, the evidence indicates that the Dirty Devil Wilderness Study Area and the southwestern part of the French Spring-Happy Canyon Wilderness Study Area, which are underlain by the authigenic dolomite, carbonaceous mudstone, and the fluvial systems, have moderate potential for containing uranium deposits (fig. 3).

The northeastern part of the French SpringHappy Canyon Wilderness Study Area and the Horseshoe Canyon Wilderness Study Area do not appear to be underlain by the authigenic dolomite, carbonaceous mudstone, or the fluvial systems. However, the distance between the outcrop of the Chinle Formation and these two study areas is considered great enough for some uncertainty to exist as to the possible location of the underlying dolomite, carbonaceous mudstone, and fluvial systems. Thus, the northeastern part of the French Spring-Happy Canyon Wilderness Study Area and the Horseshoe Canyon Wilderness Study Area are considered to have unknown potential for containing uranium deposists. They are also considered to have low potential for metallic mineral deposits other than uranium (fig. 3).

Samples of stream sediments and panned concentrates from stream sediments were analyzed to determine the potential in the study areas for metallic resources other than uranium. These analyses indicate that there is low potential for metals other than uranium in the study areas.

The Dirty Devil, French Spring-Happy Canyon, and Horseshoe Canyon Wilderness Study Areas have been assessed as having a moderate potential for oil and gas by Molenaar and others (1983) and by Molenaar and Sandberg (1983). Thirty-six wells have been drilled in and near the study areas; although oil shows have been encountered in 14 of the 36 wells, none have produced oil or gas (Schreiner, 1984). The Triassic Moenkopi Formation, the White Rim Sandstone Member of the Permian Cutler Formation, the Pennsylvanian Honaker Trail and Paradox Formations of the Hermosa Group of Wengerd and Matheny (1958), and the Mississippian Leadville Limestone, which are known to occur in the subsurface of the study areas, have contained shows of oil and gas in the test wells (Schreiner, 1984).

Of the three study areas, only the French SpringHappy Canyon Wilderness Study Area has high potential for being underlain by tar sands (oilimpregnated sandstones) (fig. 3) in the Moenkopi Formation and the White Rim Sandstone Member of the Cutler Formation (Ritzma, 1973). These deposits are part of Ritzma's (1973) Tar Sand Triangle deposit, which contains an estimated 12.5-16 billion barrels of heavy crude oil. Schreiner (1984) estimates that about 25 percent of the French Spring-Happy Canyon Wilderness Study Area is within the deposit. Assuming a uniform distribution of oil in the estimated resource area, approximately 10 percent, or $1.25-1.6$ billion barrels of oil, may underlie about 25 percent of the French Spring-Happy Canyon Wilderness Study Area. Also, $70-80$ percent of the French Spring-Happy Canyon Wilderness Study Area is in a larger area designated as the Tar Sand Triangle Special Tar Sand Area; additional oil resources may occur at depth in this area (Schreiner, 1984). Accordingly, the French Spring-Happy Canyon Wilderness Study Area is assessed as having a high potential for tar sand deposits. The potential for tar sand deposits in the Dirty Devil and Horseshoe Canyon Wilderness Study Areas is unknown.

The study areas have some potential for materials that could be used for construction purposes. Sand and gravel are present in terrace deposits along major stream courses, and most of the formations could be sources of building stone. However, larger and more accessible deposits of the same materials are available outside the study area and much closer to potential markets.

\section{REFERENCES}

Baars, D. L., 1979, The Permian System, in Baars, D. L., ed., Permianland: Four Corners Geological Society Guidebook, 9th Field Conference, p. 1-6.

Detra, D. E., Erickson, M. S., Kemp, W. M., III, and Willson, W. R., 1984, Analytical results and sample locality map of stream-sediment, heavymineral-concentrate, and rock samples from the Dirty Devil, French Spring-Happy Canyon, and Horseshoe Canyon Wilderness Study Areas (UT050-236A,B, 237), Wayne and Garfield Counties, Utah: U.S. Geological Survey Open-File Report, 84-574, 33p., 1 sheet, scale 1:50,000. 


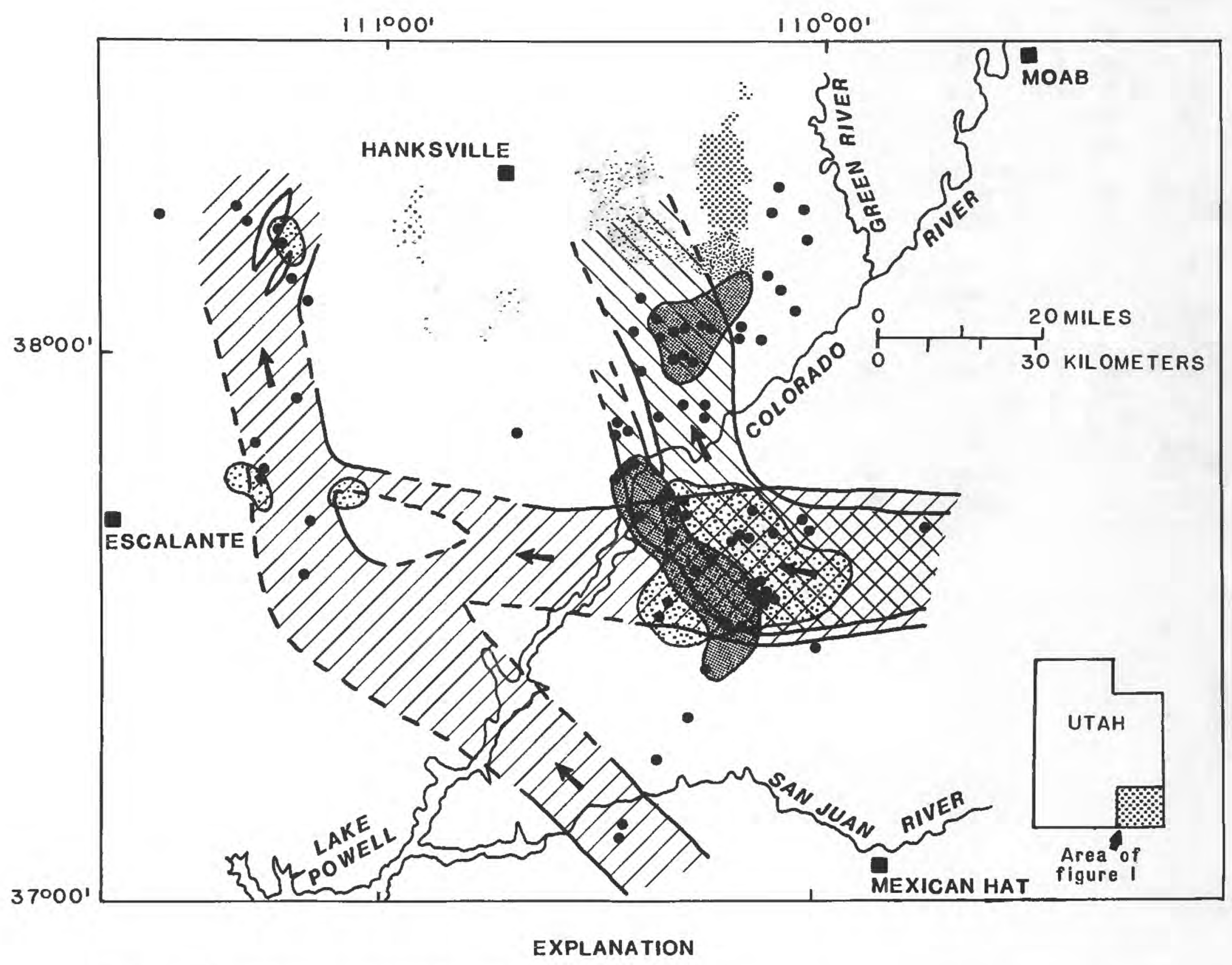

DIRTY DEVIL WILDERNESS STUDY AREA

7 SHINARUMP FLUVIAL SYSTEM--Arrow shows paleocurrent direction

FRENCH SPRING-HAPPY CANYON WILDERNESS STUDY AREA

HORSESHOE CANYON WILDERNESS STUDY AREA

MONITOR BUTTE FLUVIAL SYSTEM--ATrOW shows paleocurrent direction

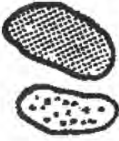
AUTHIGENIC DOLOMITE BLACK, CARBONACEOUS MUDSTONE MEASURED SECTION

Figure 4.--Map showing areas of Shinarump and Monitor Butte fluvial systems, authigenic dolomite, and black, carbonaceous mudstone used to evaluate uranium potential in the dirty Devil, French Spring-Happy Canyon, and Horseshoe Canyon Wilderness Study Areas, Wayne and Garfield Counties, Utah. 
Dubiel, R. F., 1983, Sedimentology of the lower part of the Upper Triassic Chinle Formation and its relationship to uranium deposits, White Canyon area, southeastern Utah: U.S. Geological Survey Open-File Report 83-459, 48 p.

Dubiel, R. F., Bromfield, C. S., Larson, M. J., Patterson, C. G., and Peterson, Fred, 1985, Geologic Map of the Dirty Devil, French SpringHappy Canyon, and Horseshoe Canyon Wilderness Study Areas, Wayne and Garfield Counties, Utah: U.S. Geological Survey Miscellaneous Field Studies Map MF-1754-B, scale 1:50,000.

Grimes, D. J., and Marranzino, A. P., 1968, Directcurrent arc and alternating-current spark emission spectrographic field methods for the semiquantitative analysis of geologic materials: U.S. Geological Survey Circular 591, 6 p.

Molenaar, C. A., and Sandberg, C. A., 1983, Petroleum potential of wilderness lands in Utah: U.S. Geological Survey Circular 902-K, 13 p.

Molenaar, C. A., Sandberg, C. A., and Powers, R. B., 1983, Petroleum potential of wilderness lands, Utah: U.S. Geological Survey Miscellaneous Investigations Series Map I-1545, scale $1: 1,000,000$.
Northrop, H. R., 1982, Origin of the tabular-type vanadium-uranium deposits in the Henry structural basin, Utah: Golden, Colo., Colorado School of Mines, unpublished Ph. D. thesis, T2614, $340 \mathrm{p}$.

Peterson, Fred, 1980, Sedimentology as a strategy for uranium exploration--concepts gained from analysis of a uranium-bearing depositional sequence in the Morrison Formation of southcentral Utah, in Turner-Peterson, C. E., ed., Uranium in sedimentary rocks--application of the facies concept to exploration: Rocky Mountain Section, Society of Economic Paleontologists and Mineralogists, p. 65-126.

Ritzma, H. R., 1973, Oil-impregnated rock deposits of Utah: Utah Geological and Mineralogical Survey Map 33, scale 1:1,000,000.

Schreiner, R. A. 1984, Mineral investigation of the Dirty Devil, French Spring-Happy Canyon and Horseshoe Canyon Wilderness Study Areas, Wayne and Garfield Counties, Utah: U.S. Bureau of Mines Open-File Report MLA 25-84, 22 p.

Wengerd, S. A. and Matheny, M. L., 1958, Pennsylvanian System of Four Corners Region: American Association of Petroleum Geologists Bulletin, v. 42, no. 9, p. 2048-2106. 